sciendo Порівняльна професійна педагогіка 8(2)/2018 Comparative Professional Pedagogy 8(2)/2018

DOI: $10.2478 /$ rpp-2018-0017

Doctor of Science in Pedagogy, Assistant Professor, KARINA SZAFRAŃSKA The Christian Academy of Theology, Warsaw, Poland Address: 21 C Miodow St., Warsaw, 00-246, Poland E- mail: Karina.szafranska@sonica.com.pl

\title{
LIFE GOALS OF YOUNG PEOPLE AT RISK OF SOCIAL EXCLUSION IN POLAND
}

\begin{abstract}
Every young person in adolescence is looking for the meaning of life, concentrating their activities around specific goals. Selecting them independently, they are guided by specific values, strive to reach them by orientating themselves to the world in a specific way. An analysis of the ever-changing reality and its interpretation make it easier for them to function in the world and make choices. The decisions they take refer to different areas of life, have different levels of importance, degree of involvement in the action leading to implementation of the intentions. The first part of the article presents selected concepts of purposeful behaviour, depicting human activity in the category of goals set by an individual. These concepts are characterized primarily by individual life goals, their properties and mechanisms governing them. The second part of the article will present results of research on the life goals of pupils of Youth Educational Centres (YEC) in Poland. On the basis of the obtained results it can be noticed that the respondents obtained average results on all the scales - only in the case of the following goals: finances and permanent relationship were the results increased. This shows that it is important for them to start a family and have financial security in the future. Results of the Mann-Whitney $U$ Test indicate that girls significantly higher than boys appreciate in their lives such goals as: permanent relationship, finances and society (statistically significant differences at the level of at least $p$ <0.05). In addition, in the case of the indicated life goal scales, a trend is observed showing that along with the number of resocialization programs in which the respondents participate, the results obtained in the scale of assessing the importance of all life goals increased. It is therefore important to pay more attention to supporting and developing socially accepted life goals of young people at risk of social exclusion as this can significantly increase the effectiveness of rehabilitation interactions.

Keywords: life goals, adolescence, young people at risk of social exclusion, Youth Educational Centres.

\section{INTRODUCTION}

The problem of shaping life goals and values in the study of young people has been undertaken in two areas: explaining the development of an adult development before adulthood. In the latter area, the shaping of the value system was treated as implementation of one of the developmental tasks as presented by Robert J. Havighurst (Havighurst, 1981) or part of the content aspect of identity, in the Eriksonian tradition (Cieciuch, 2007). Human development takes place through the achievement of developmental tasks and maturation of his personality structures. Cognitive processes expressed through perceptual activity (perception, assessment, attribution and valuation of social events and behaviours)
\end{abstract}


sciendo Порівняльна професійна педагогіка 8(2)/2018

Comparative Professional Pedagogy 8(2)/2018

are extremely important during adaptation of an individual in the social environment. The adaptation process is understood as passive adoption of the required behavioural patterns, as well as the active innovative action of the individual; it is also an effort allowing maintaining a dynamic state of balance of cognitive structures, enabling a young person to develop identity and achieve personality integrity. This gives a chance to maturely take on social roles and participate in social life. Adolescence is a period of identity crisis whose the positive resolution of which determines the achievement of the maturity of personality structures. Research shows that the worldview of young people at this time shows signs of instability and incoherence (Kwiecinski, 1987), which results from the comprehensive process of changes in the level of psychological organization, accompanying the creation of the intellectual representation of the world, combined with its evaluation. It is also connected with making attempts to deliberately build the concept of oneself by rejecting the authorities from earlier stages of development, and making autonomous choices regarding participation in social life. According to Lawrence Kolhberg, this is the time of the postconventional level of moral development, when the valuation of other people's behaviour is based on social approval (mainly peers' attitudes), and moral assessments show autonomic features independent of previous authorities and are characterized by a significant degree of internalization (Kolhberg, 1984). During reconstruction of the mental structure towards a morally and socially mature one, the following is important: increase in the cognitive competence of a young person, experience from interaction with peers, but also - as Goleman emphasizes - emotional relations with the family environment (Goleman, 1997). The intensive growth of cognitive and socio-moral development causes progressive changes in the structure and quality of assessment and valuation of other people as well as social events. Therefore, the process of building the value system is intrapsychic and interpsychic. Adaptation standards that regulate the behaviour of an individual include adaptive behaviours: accommodative behaviours, conditioned by motivation to change and transform the environment (Szafraniec, 1990). Adolescents are characterized by a lack of full social competences, allowing the generalizing application of social rules in different situations. This phenomenon can be analyzed in the light of the hypothesis of insufficient operational competence of R. Bohnsack (Bohnsack, 1973), who, in a limited range of experiences and social skills, sees the reasons for a faulty or incorrect assessment of the interaction partner, similarly to planning activities in the short term and incomplete adoption of roles resulting from imperfect generalization, insufficient generalization and attribution. This may give rise to threats in socio-moral development or encourage interaction with people with similar experiences of social incompetence, which in turn results in the formation of peer groups at risk of risky behaviours or criminalization. Such a state favours the creation of an "existential vacuum" that makes it impossible to give meaning to own life and reduces it to the dimension of quick and easy consumption. This promotes behaviours characterized by egoism, lack of responsibility and impossibility to set life goals properly. Young people may present various forms of risky behaviour and demonstrate passive, defensive attitudes and lack of interest in social reality. As a consequence, it may result in entering into conflict with the law. From this point of view, it is important to undertake research on the processes of shaping life goals of young people and identification of factors directing their moral development and the ability to handle mature evaluation criteria. Getting to know and then stimulating development, socially accepted life goals of YEC pupils can significantly contribute to the effectiveness of their resocialization. 


\section{THE AIM OF THE STUDY}

The aim of this article is to present results of research on the life goals of young people staying in the Youth Educational Centres of the Mazowieckie Voivodeship.

\section{THEORETICAL FRAMEWORK AND REASERCH METHODS}

The concept of purpose can be found in many ideas of motivation and personality, e.g. by Albert Bandura, Martin E. Ford, Gary P. Latham, Edwin A. Locke, Lawrence A. Pervin. The concept of goals as behaviour regulators is an important current in modern psychology; it indicates that having a goal and striving to reach it structures daily activity and gives it meaning. Zbigniew Zaleski (Zaleski, 1991) considers goals as cognitive constructs appearing at the conceptual level, perceived as a future reality and defines them as possible to achieve future states of things to which a man strives when undertaking action. These states are characterized by a certain value, regulatory force and cognitive representation. The term "cognitive" refers to the thought processes and the nature of their effects (perception of objects, comparing and coding an imagined standard in permanent memory). The goal is usually an anticipated, potential state because it refers to the future. It becomes realistic if it is feasible and the individual takes action to achieve it. If the human behaviour changes under the influence of this activity, we deal with the power of regulation, characterizing the behavioural functionality. Thanks to the involvement in action, emotional states arise, the so-called emotional experience indicators.

Jerome Kagan (Kagan, 1972) defines the goal as "a cognitive representation of an event in the future", as to which the individual has a belief that it serves his well-being, both physical and mental. However, Eric Klinge (Klinger, 1997) believes that a goal is an object or event that motivates the pursuit of activity, and Jari-Erik Nurmi (Nurmi, 1991) sees the goal as an imagined change in the environment of the individual, achievable through action and serving the optimal functioning of man.

The relationship between setting tasks (goals) and human behaviour is explained by the concept of distant tasks by Kazimierz Obuchowski. The researcher defines tasks as formations of the "intentional Self", i.e. the basic category of human motivation, different from inner drives, which constitute a component of the "subjective Self", as well as various external pressures (requirements). According to Obuchowski, the central personality function is related to forecasting the states of things and adjusting one's actions to them (Obuchowski, 1999). In the researcher's concept, we distinguish two types of motivation, concerning tasks: short-term conditioned by the situation, state of emotions or experience and distant, the source of which is reflection. Distant tasks are the result of human thinking about specific situations, taking into account the goals of the action and a specific concept of its implementation.

According to Dariusz Doliński and Wiesław Łukaszewski, the goal is a task, accompanied by the triggered tendency to achieve it; this is a type of possibility that may or may not be achieved. Assigning the value to the imagined result and intention of action, focused on the result, decide on the transformation of the action into a goal (Lukaszewski, Doliński, 2000). Having a goal and striving to achieve it structures human activity. The theories of goals show man as a self-motivating subject, able to self-regulate his behaviour by constructing significant goals and striving to achieve them through his oriented activity. Goals are also an element supporting the development of personality, if they are in harmony with the system of values and the philosophy of life. They are also an important factor in its meaning (Zaleski, 1991). 
sciendo Порівняльна професійна педагогіка 8(2)/2018

Comparative Professional Pedagogy 8(2)/2018

All these theories analyze human activity in terms of goals (set and achieved), indicating the universality of human aspirations, reflecting his development. They characterize life goals, their properties and related mechanisms in different phases of life. The term "goal" may be interpreted depending on the adopted theory and its proper terminology; as synonyms, the authors also use other concepts (Zaleski, 1991): aspirations, plans or life orientations.

Albert Bandura (Bandura, 1997), similar to Kurt Levin and Jozef Nuttin (Levin, 1963; Nuttin, 1980), believes that the sources of goals should be sought in the dynamics of learning (through observation or imitation - vicarious learning), based on social models of various forms of behaviour, assessment criteria, as well as ways of valuing and striving. Seeking the relationship between goals and the theory of needs, they believed that the pursuit of achieving goals results from their satisfaction. Rokeach believes that the functioning of a person changes permanently when the preferences within his hierarchy of values evolve. In people with permanent incompatibilities in the existing hierarchy of values (mental disorders, neurosis, personality disorders), consisting in a significant difference in the structure of instrumental values (implemented in reality) and finally declared as principal, changes can occur, for example, under the influence of rehabilitation activities or psychological therapy (Rokeach, \& McLellan, 1972). Unification (in accordance with socially accepted values) of the value system is extremely important because this system, being an element of personality, affects the behaviour of the person, his intentions and the formulation of personal goals. Therefore, one of the goals of resocialization is to bring about a mature and stable structure of values.

Characterization of the concept of functional autonomy, and thus defining a man as an independent, autonomous system means:

1. Developing an autonomous motivation, directing own actions to the goal (as the intrinsic motivation for action - intention), characteristic of future orientation.

2. The advantage of one intention over others as a feature of human decisions.

3. Interests and values as a source of motivation.

4. The emergence of motivation that fully integrates with most aspects of personality (Gierowski, 1985).

According to Nuttin, the mechanisms of life goals setting are different from dreams and imaginations. They require taking steps through their implementation, step by step, over a long period, in different circumstances, they can cognitively be included in one aspect and verified from different perspectives, including reachability (reality). Nevertheless, dreams and fantasies are conducive to goals setting, they are a prelude to effective behaviours, acting as a preparatory activity. Everyone has the ability to create standards, ideas regulating his behaviour, and the developed standards become personal goals, the achievement of which is conditioned by the consistent implementation of many stages, called sub-goals or instrumental goals by Nuttin that are determinants of achieving the ultimate goal.

The literature on the subject only partially explains the planning processes of adolescents. The authors (Sikorski, 1999; Mac-Czarnik, 2000) pay attention mainly to the decision making process. In the psychological literature, however, there is no empirical analysis of the process as a whole or research of individual planning components. It is essential that life goals are always set by the objective conditions of the society in which an adolescent lives and his individual predispositions (Sułek, 1989). 
Characteristics of the sample group. The study covered 456 people aged 17 to 20 years $(\mathrm{M}=17.3, \mathrm{SD}=0.68)$ staying in YECs in the Mazowieckie Voivodeship. Pursuant to the act on proceedings in juvenile cases, pupils stay at YECs up to the age of 18 , but the study also covers people who have been emancipated 35 people $(n=35)$, staying in protected flats or branches of the centres. In the group of respondents, women accounted for $59.2 \%$, while men accounted for $40.8 \%$. At present, there are 5,468 pupils in 37 YECs in Poland: 3,729 boys and 1.733 girls (according to the SIO Education Information System dated 5 April 2016, ore.edu.pl). Such a large number of girls taking part in the study results from the specificity of the centres in the Mazowieckie Voivodeship: 6 centres for girls, 5 co-educational ones, 9 for boys) and from the fact that the study covered those individuals who had volunteered to participate in the research. Therefore, the selection of individuals for the study should be treated as a purposeful choice. At the study stage, a possible representative youth sample was sought. Gender, age and period of stay in the YEC were controlled. Where there were clear disproportions between the tested sample and the youth population from the YEC, analytical weights will be prepared to ensure high reliability and accuracy of the conclusions drawn.

Quantitative research provides information allowing compiling data in a way that allows finding answers to questions that require estimation and construction of probabilistic models. The measurement made using these methods allows obtaining multifactorial statistical characteristics enabling exploration, description and explanation of the problem in parametric-index analysis of data. Therefore, the quantitative survey is an indeximportant method of gathering information. The study requires a suitably selected research sample that ensures the representativeness and correctness of the conclusions drawn.

The Polish adaptation of the Aspiration Index questionnaire (Kasser, Ryan, 1993), conducted by Ewa Wojtowicz was used to measure life goals. The questionnaire measures how important for the respondent are the individual life goals, which in accordance with the assumptions of the self-determination theory are treated mostly as intrinsic goals (with the exception of financial goals). The questionnaire can be used in both individual diagnosis and research.

The questionnaire consists of 22 items; the task of the respondents is to determine on a 6-point Likert-type scale (1 - I do not care at all, 6 - I really care), how much they want to achieve a given goal. According to the original version, four items were related to self-acceptance goals, seven test items characterize interest in activity for the world and society (community feeling), the next five items describe the interest of the respondents in material goods and focus on acquiring money (Financial success) and seven items measure goals related to the expectation of love and the desire to be surround by close people (Affiliation).

\section{RESULTS}

Results of the factor analysis carried out by Ewa Wojtowicz partially confirmed the factor structure adopted by the Questionnaire Authors. The existence of factors such as self-acceptance, financial success and society was confirmed, while the "affiliation" factor was divided into two independent scales: permanent relationship and friends. In addition, for all factors, with the exception of the "permanent relationship" scale, satisfactory Cronbach's Alpha Reliability Coefficients were obtained (Wojtowicz, 2009).

Research questions

1. What are the life goals of YEC pupils? 
2. Do the goals of YEC pupils differ from the life goals declared by youths in the study by CBOS (Public Opinion Research Centre)?

The most important life goals were starting a family, relationship based on love, having a job, friends and honesty. Money is an important value in life for approx. $21 \%$; when asked directly about whether money is important, almost $49 \%$ answered yes.

In addition, life goals (values) were compared with results of the research published by CBOS (2016) (Centrum Badań Opinii Społecznej, 2016), which was carried out on a random sample of 82 secondary schools (a total of 1,724 pupils were examined). The results point to acertain coherence: in both groups, the most cherished values (life goals) are: love, friendship, successful family life and starting work in line with interests (see Fig. 1). It is worth noting, however, that in the group of YEC pupils, a significantly higher percentage indicated life goals such as starting a relationship based on love, having family and friends, which may result from deficits of the YEC pupils in this area and difficult family situation of most of them.

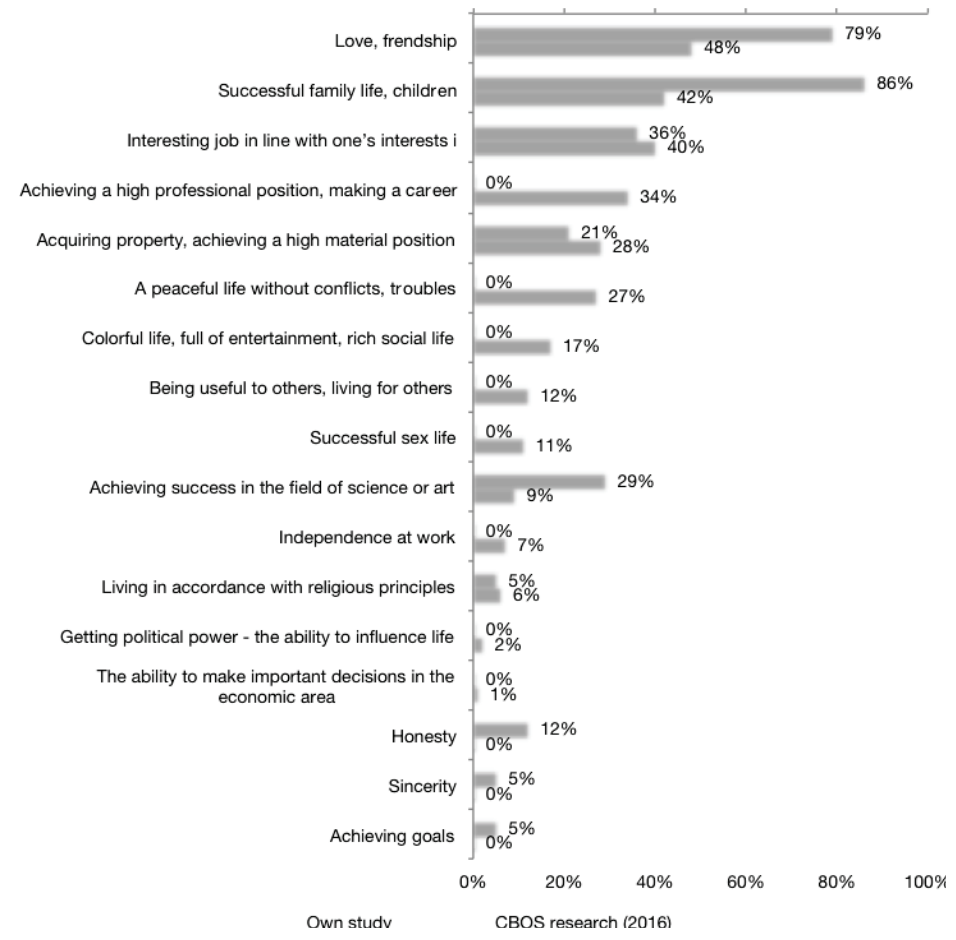

Fig. 1. Values held high in life - comparison of YES pupils with a representative group of young people

Interestingly, YEC pupils did not indicate such values as: achieving a high professional position, a peaceful life without problems, colourful life, rich social life, being useful to others and a successful sex life (these values were indicated by at least $10 \%$ of the nationwide youth sample in the CBOS study). Perhaps they associate a rich social life or sexual activity with life before the stay in the centre and the negative consequences of their 
risky behaviour. YEC pupils, unlike young people from the CBOS research, pointed to life goals such as honesty, sincerity and effectiveness in achieving the goal, which may indicate the effectiveness of resocialization and positive moral development of YEC pupils. Another explanation may be higher awareness of the pupils of the importance of these values and the willingness to present themselves in a better light (perhaps it is one of the defence mechanisms in YEC pupils).

Table 2 presents basic descriptive statistics for the analyzed variables characterizing life goals.

Table 2

Life goals - descriptive statistics

\begin{tabular}{|l|c|c|c|c|c|c|}
\hline \multicolumn{1}{|c|}{ Life goals } & Min. & Max. & M & SD & Skewness & Kurtosis \\
\hline goals - society & 1.0 & 6.0 & 4.62 & 1.01 & -1.13 & 1.72 \\
\hline goals - finances & 1.0 & 6.0 & 4.99 & 1.09 & -1.63 & 2,70 \\
\hline goals - self-acceptance & 1.0 & 6.0 & 4.67 & 1.15 & -0.84 & 0.51 \\
\hline goals - friends & 1.0 & 6.0 & 4.17 & 1.17 & -0.48 & 0.13 \\
\hline goals - permanent relationship & 1.0 & 6.0 & 5.23 & 1.08 & -1.98 & 3.87 \\
\hline
\end{tabular}

\section{CONCLUSIONS}

On the basis of the obtained results it can be noticed that the respondents obtained average results on all the scales - only in the case of the following goals: finances and permanent relationship were the results increased. This shows that it is important for them to start a family and have financial security in the future. Results of the Mann-Whitney U Test indicate that girls significantly higher than boys appreciate in their lives such goals as: permanent relationship, finances and society (statistically significant differences at the level of at least $p<0.05$ ). In addition, in the case of the indicated life goal scales, a trend is observed showing that along with the number of resocialization programs in which the respondents participate, the results obtained in the scale of assessing the importance of all life goals increased. It is therefore important to pay more attention to supporting and developing socially accepted life goals of young people at risk of social exclusion as this can significantly increase the effectiveness of rehabilitation interactions.

\section{REFERENCES}

1. Bandura, A. (1997). Social learning theory. New York: Pretice Hall.

2. Bohnsack, R. (1973). Handlungskompetenz und Jungendkriminalitat. Berlin: Neuwied.

3. Centrum Badań Opinii Społecznej. (2016). Młodzież 2016. Raport z badania sfinansowanego przez Krajowe Biuro ds. Przeciwdziałania Narkomanii.

4. Cieciuch, J. (2007). Relacje między systemami wartości a przekonaniami światopogladowymi w okresie dorastania. Warsaw: Wydawnictwo UW. 
sciendo Порівняльна професійна педагогіка 8(2)/2018

Comparative Professional Pedagogy 8(2)/2018

5. Czerwińska-Jasiewicz, M. (2005). Rozwój psychiczny młodzieży a jej koncepcje dotyczace własnego życia. Warsaw: Wydawnictwo Instytutu Psychologii PAN.

6. Gierowski, J. K. (1985). Diagnoza procesów motywacyjnych jako przedmiot opinii sądowo- psychologicznej. In J. M. Stanik (Ed.), Problemy psychologicznopsychiatryczne w procesie karnym (p. 51). Katowice: Wydawnictwo UŚ.

7. Goleman, D. (1997). Inteligencja emocjonalna. Poznań: Media Rodzina.

8. Havighurst, R. J. (1981). Developmental tasks and education. New York, NY: Longmans \& Green.

9. Kagan, J. (1972). Motives and development. Journal of Personality and Social Psychology, 29, 109-230.

10. Kasser, T., \& Ryan, R. M. (1993). A dark side of the American dream: Correlates of financial success as a central life aspiration. Journal of Personality and Social Psychology, 65, 410- 422.

11. Klinger, E. (1997). Meaning and void: Inner experience and the incentives in peoples lives. Minneapolis, MN: University of Minnesota Press. Harper \& Row.

12. Kolhberg, L. (1984). The psychology of moral development. New York, NY:

13. Kwieciński, Z. (1987). Młodzież wobec wartości i norm życia społecznego, Toruń: UMK, 1987, pp. 53-55;T. Kluz, op. cit., p. 17

14. Levin, K. (1963). A dynamic theory of personality. New York, NY: McGraw-Hill.

15. Łukaszewski, W., \& Doliński, D. (2000). Mechanizmy leżace u podstaw motywacji. In J. Strelau (Ed.), Psychologia. Podręcznik akademicki (Vol. 2). Gdańsk: Gdańskie Wydawnictwo Psychologiczne.

16. Mac-Czarnik, L. (2000). Procesy poznawcze w planowaniu własnego życia $u$ młodzieży. Rzeszów: Wydawnictwo WSP.

17. Nurmi, J. E. (1991). How do Adolescents see their future: a review of the development of the future orientation and planning. New York, NY: Oxford University Press.

18. Nuttin, J. (1980). Motivation et perspective d'avenir. Louvain: Presses Universitaires de Louvain.

19. Obuchowski, K. (1999). Galaktyka potrzeb. Psychologia dążé́ ludzkich. Poznań: Zysk i S-ka.

20. Rokeach, M., \& McLellan, D. (1972). Feedback of information about the values and attitudes of self and alters as determinants of long term cognitive and behavioral change. Journal of Applied Social Psychology, 2, 236-256.

21. Sułek, A. (1989). Wartości życiowe dwóch pokoleń. In S. Nowak (Ed.), Ciagłość i zmiana w tradycji kulturowej. Warsaw: PWN.

22. Sikorski, W. (1999). Aspiracje młodzieży uczacej się i ich tlo rozwojowe. Opole: Wydawnictwo Uniwersytetu Opolskiego.

23. Sikorski, W. (1997). Aspiracje edukacyjno-zawodowe młodzieży niedostosowanej społecznie. Szkoła Specjalna, 2, 70-77.

24. Szafraniec, K. (1990). Anomia - przesilenie tożsamości. Jednostka $i$ spoleczeństwo w okresie zmiany. Toruń: Wydawnictwo UMK.

25. Wojtowicz, E. (2009). Przekonania dotyczące natury ludzkiej, cele życiowe a oczekiwania $i$ satysfakcja z pierwszej pracy. Unpublished $\mathrm{PhD}$ thesis - Uniwersytet SWPS, Warsaw.

26. Zaleski, Z. (1991). Psychologia zachowań celowych. Warsaw: PWN

27. Zaleski, Z. (1986. Motywacyjna funkcja celów stawianych na okresy o różnej długości. Przegląd Psychologiczny”, XXIX, 4. 